UDC $504.65(043)$

Grigory M. Franchuk, D. E., Prof. Margaryta M. Radomska, post-graduated, student

\title{
CONCEPTUAL MODELS DEVELOPMENT FOR ENVIRONMENTAL RISKS ASSESSMENT
}

The basics of conceptual models are presented in the article. Practical application of environmental conceptual models to the process of environmental risks assessment process is given. Structural issues of models formation are presented and most common types of conceptual models are analyzed. Recommendations for site-specific models construction are developed for various organizational levels and types of receptors. The scheme for integration of ecological conceptual model with conceptual model for the industrial site is presented and approaches to making them consistent with the conceptual model of human health risks are stated.

Розглянуто теоретичні основи концептуальних моделей та практичне застосування екологічних концептуальних моделей у процесі оцінки екологічних ризиків. Наведено структурні елементи формування концептуальних моделей $i$ проаналізовано ̈̈х основні типи. Розроблено рекомендації для побудови спеціалізованих моделей на різних організаційних рівнях і для різних типів рецепторів. Подано схему інтеграції екологічних і спеціалізованих під конкретні промислові об'єкти конщептуальних моделей та підходи до їх узгодження з концептуальними моделями ризиків для здоров'я людей.

\section{Introduction}

Environmental risk assessment is a complex scientific problem. Possible solutions may give information on probability and magnitude of accidents and negative phenomena mostly associated with industrial objects. A lot of approaches describe various ways of mathematical and experimental evaluations. But they can be applied when some essential background information is available for investigation. So, there is a real need for a theoretic model of risk nature, realization and consequences in terms of each investigated object. This model is based on integral features and properties of the studied object and can serve as its structured description useful for hypothesis to be set up. Such models are called conceptual and they can be decisive for successful risk assessment. They are usually called ecological as they are referred to natural preconditions of various anthropogenic processes.

\section{Concept and methods}

Ecological conceptual models are the result of the problem formulation phase of an ecological risk assessment. They may be thought of as a hypothesis concerning the nature of ecological risk at a contaminated site. They include the hypothesized sources of contamination, contaminants transport routes, contaminated media, exposure routes, and endpoint receptors. They are presented in the form of a flow chart and a descriptive narrative. All screening and baseline ecological risk assessments should use and present the conceptual model.

\section{Results and recommendations}

Conceptual models should be presented for any current case and for any credible future cases that could result in increased risk. The same conceptual model can be used for the baseline ecological risk assessment in the remedial investigation (RI) and for the reductions in risk associated with the remedial actions assessed in the feasibility study (FS). However, the ecological risks associated with the physical damage caused by remedial actions require separate conceptual models.

First, following the initial site survey, draft conceptual models should be developed as input to the risk assessment process. These models should be all-inclusive as they should include all sources, receptor classes, and routes of exposure that are of real concern. Then, they are refined and thereby made more focused during the process of data quality control (DQC). This refinement is done by eliminating receptors that are not deemed to be suitable assessment endpoints, routes of exposure and potential sources that are not credible or important, routes of exposure, that do not lead to endpoint receptors. In addition, the DQC process makes the conceptual model more specific by identifying particular endpoint species, defining the spatial and temporal scale of the assessment, and other judgments. At this stage it is possible to make particular conceptual model for different types of industrial projects or types of enterprises.

The bases for developing the conceptual models depend on the stage of the risk assessment and the amount of prior assessment that has been done at that stage. 
The first conceptual model is based on qualitative evaluation of existing information and expert judgment. It should be conservative in the sense that sources, pathways, and receptors should be deleted only if they are clearly not applicable to the site.

Early in the RI/FS process, preferably before or during the DQC process, a screening assessment should be performed using existing data. The results of the screening assessment can be used to eliminate receptors or even an entire medium for which no contaminants present a potentially significant risk.

The participants in the DQC process can apply their professional judgment and managerial authority to modify the draft conceptual model presented by assessment scientists. Some receptors may be eliminated because they are not judged to be sufficiently important or sensitive or not sufficiently relative.

Conceptual models can be formed for any object and used in all researches related to it, but they should be amended as soon as additional factors which may have any kind of notable effect appear (e.g., new endpoint receptors or conditions).

Generic conceptual models are presented for four types of operable units (OUs): source OUs, aquatic integrator OUs, groundwater integrator OUs, and terrestrial integrator OUs. A conceptual model should be presented in both graphic and narrative form. The graphic form may be pictorial (i.e., with drawings of plants and animals), but pictorial representations are typically costly to produce and often ambiguous. Therefore, flow charts are generally recommended. The charts should include sources, routes of transport from sources to contaminated media, routes of exposure of receptors to media, endpoint receptors, and output to other OUs. In addition, the narrative conceptual model should explain the underlying logic of the model including the following:

- it should describe the spatial bounds of the assessment and any subdivision of the site into regions or other subunits;

- if receptors or routes of exposure are omitted due to lack of information or knowledge or expert judgment, that omission should be acknowledged and included in the analysis of uncertainty;

- if receptors are representatives of a class of receptors, then that relationship should be explained.
All conceptual models for contaminated sites begin with sources. On source OUs, for example, the wastes deposited in pits, trenches, ponds, tanks, etc. are treated as the ultimate sources. Each distinct type of ultimate source should be identified in a separate box. Types of sources should be distinguished when they contain wastes that are distinctly different in form or composition or when the wastes are disposed of in different manners (e.g., ponds versus tanks) or in situations that would result in different modes of transport.

Integrator OUs usually have no ultimate sources, but they have as proximate sources the contaminated inorganic media: surface water, shallow groundwater, sediments, and soils. These may be in the form of fluxes of surface water, groundwater, eroded soil, or suspended sediments and should be identified in terms of their nature and source. In addition, some proximate sources are not associated with any ultimate source. For example, soils may be contaminated by past spills or other actions to which no ultimate source or upstream source is contributing.

The conceptual model points out the routes by which contaminants in the sources are transferred to ambient media to which organisms may be exposed. The routes of transport for ecological conceptual models do not normally include deep groundwater transport because it does not contribute to surface water contamination and because wildlife does not drink well water [1]. However, it must be considered if the model includes human endpoints.

The conceptual model should identify the media that is known to be significantly contaminated, is hypothesized to currently be significantly contaminated, or is predicted to be significantly contaminated in the future. If possible, significance of contamination should be based on the results of an assessment that compares screening of measured contaminant concentrations against ecotoxicological benchmarks and background concentrations [2]. A medium should be included in the model if any chemical in the medium is retained by the screening process or any chemical is judged to potentially be present at significant concentrations.

The conceptual model describes the routes of exposure that are assumed to result in uptake of chemicals from contaminated organic and inorganic media. The number of routes of exposure is limited 
to those that are deemed to be important for the endpoint receptors. The following points should be considered.

Fish, aquatic invertebrates, and aquatic plants are assumed to be exposed to contaminants in water. Conventionally, the EPA and most risk assessors have assumed that dietary exposures are negligible and that is likely to be true for most chemicals. This is reasonable given the relatively high rate of exposure of organisms to chemicals in the water that pass their respiratory surfaces and the fact that most chemicals are not highly bioaccumulative and do not biomagnify [3]. It also should be noted that appropriate dietary exposure models and toxicity information based on dietary exposure is uncommon and poorly standardized.

Benthic invertebrates are exposed to sediment pore water and whole sediment.

Terrestrial organisms, including wildlife and humans. Their exposure routes usually include ingestion of food, drinking water, and incidental soil ingestion.

Dermal exposure should be considered for humans only, as birds and mammalian wildlife are covered with feathers and fur. These coverings exclude most dermal exposures. However, they create another route of exposure: grooming and preening, which contribute to incidental soil ingestion. Amphibians are likely to experience significant dermal uptake, but neither exposure models nor toxicity data are available to address this route and receptor for terrestrial exposures [4]. Aqueous dermal exposures for amphibians are equivalent to respiratory exposure of fish in that they are assumed to be due to direct uptake of dissolved chemicals through the respiratory epithelium, which is the skin.

Respiratory exposure is also normally considered for humans and mammals.

Plants, soil invertebrates, and soil microbes are assumed to be directly exposed to whole soil.

In cases where shallow groundwater is contaminated, plants are exposed to that water.

The receptors presented in the conceptual model should be those that have been proposed to be or designated as assessment endpoint receptors (organisms, populations, communities, or ecosystems).

Ecosystems are assessment endpoints if the properties to be protected are ecosystem properties.
This is the case for wetlands which are protected for their habitat value to wetland-dependent species and their roles in nutrient retention and cycling and hydrologic regulation. A component of an ecosystem that is valued for its functional properties rather than its community or population properties may also be considered an ecosystem-level endpoint.

Fishes, benthic macroinvertebrates, soil invertebrates, and upland plants are community level assessment endpoints. That is, the species richness and abundance of the communities are the endpoint properties rather than properties of the component populations.

Most wildlife is population level assessment endpoint. The endpoint properties are abundance and production of individual populations. The populations used are chosen to represent a particular trophic group and taxonomic class (i.e., birds and mammals). The conceptual model should identify these receptors both in terms of the species and location of the population and the group that they represent. Human settlements are considered as populations, however further risk assessment normally addresses individual humans.

The generic conceptual models include indirect routes of exposure (i.e., food web transfers) but not indirect effects. An endpoint may be affected indirectly through toxic effects on lower trophic groups, by toxic effects on groups that provide physical habitat, or by other mechanisms. The importance of explicitly including indirect effects depends on the nature of the ecological relationship that causes the indirect effect and the relative sensitivity of the groups involved.

It is also obvious that all OUs are responsible for characterizing their contributions of contaminants to other OUs. This responsibility is visible with respect to hydrologically transported contaminants, where conceptual model should show connections to downstream aquatic integrator OUs and groundwater OUs and connections to the terrestrial integrator OU. And again the conceptual model for ecological risks, which is often thought as related to wildlife, must be consistent with the conceptual model for human health risks if that is the question. That is, it should identify the same contaminant sources, contaminants transport routes, and contaminated media. However, the routes of exposure and receptors will be different. 
Some RIs will have an overall conceptual model for the OU [4-5]. Such models depict the sources and contaminants transport routes. They may emphasize particular physical aspects of the site such as surface flow patterns or the relationship between groundwater transport and geological stratigraphy. They may be in the form of maps showing, for example, the location of streams and seeps relative to wastes and drainage patterns. The ecological conceptual models should be consistent with these more general conceptual models and should refer back to them to provide the reader of the ecological risk assessment a context for the ecological conceptual model.

\section{Conclusion}

Ideally, the ecological conceptual models should be an extension and elaboration of a generic conceptual model for the site. The generic conceptual model would identify such components as the sources, the contaminants transport routes from the sources, the contaminated media, and the transport of contaminants out of the OU.
The ecological conceptual model as well as the human health conceptual model could then be limited to these components that are particular to ecological and health risks.

Such models are of great help in the work devoted to prognosis and evaluation of risks related to any area of human activity, industrial site or natural object presenting all valuable information on their physical and biological features, connections and interrelations.

\section{References}

1. Risk Assessment Guidance for Superfund. Washington: EPA Risk Assessment Forum, 1994. - 231 p.

2. Suter G. W. II. Guide for Developing Conceptual Models for Ecological Risk Assessments. - Oak Ridge: U.S. Department of Energy, 1999. - 23 p.

3. Framework for ecological risk assessment. Washington: EPA Risk Assessment Forum, 2001. - 146 p. 4. A review of ecological assessment case studies from a risk assessment perspective. - Washington: EPA Risk Assessment Forum, 2001. - 146 p.

5. Risk comparison and environmental priorities setting. Manchester: Lindon Press, 2000. -347 p.

The editors received the article on 21 May 2008. 